\title{
Detection of Helicobacter pylori and its virulence genes (cagA, dupA, and vacA) among patients with gastroduodenal diseases in Chris Hani Baragwanath Academic Hospital, South Africa
}

\author{
Ayodeji Idowu ${ }^{1 *}$ (D, Asisipho Mzukwa', Ute Harrison², Pia Palamides², Rainer Haas², Melvin Mbao³, \\ Razinah Mamdoo ${ }^{3}$, Jonathan Bolon ${ }^{3}$, Tolulope Jolaiya ${ }^{4}$, Stella Smith ${ }^{5}$, Reidwaan Ally ${ }^{3}$, Anna Clarke ${ }^{1}$ and \\ Henry Njom ${ }^{1}$
}

\begin{abstract}
Background: The global prevalence of $\mathrm{H}$. pylori approaches 50\%, with prevalence rates between 20 and $40 \%$ in developed countries and up to $90 \%$ in Africa and other developing nations of the world. Development of H. pylori-associated diseases is determined by a number of virulence factors. This study aimed at determining the prevalence of $\mathrm{H}$. pylori infections and virulence genes (cagA, dupA, and vacA); the relationship between virulence factors and gastroduodenal diseases among patients.
\end{abstract}

Methods: Gastric biopsies were obtained from patients and cultured, DNA was extracted from cultured isolates and biopsies for PCR assay after which samples were investigated using standard laboratory procedures. Data of associated risk factors were obtained with the aid of questionnaires.

Results: Of the 444 participants, H. pylori was detected in 115 (25.9\%) from culture analysis and 217 (48.9\%) by direct PCR method. Ninety-eight (85.2\%) of the culture-positive patients were also detected by PCR giving an overall prevalence of $52.7 \%$ (234/444). The highest number of $H$. pylori isolates $76.9 \%(180 / 234)$ was obtained from patients suffering from pangastritis. The CagA virulence gene was found in 62\% (145/234), dupA in 53.4\% (125/234) and vacA in 90.6\% (212/234). VacA genotype s1 m1 was the most prevalent [56.4\% (132)] followed by s2 m2 [11.5\% (27)], s2 m1 [10.3\% (24)] and [s1 m2 9.4\% (22)]. There was a significant association observed in vacA s1 and peptic ulcer disease, as well as vacA s1/m2 and gastric erosion $(P<0.05)$. Conclusion: The study revealed a significant association between virulence genes and the development of certain forms of gastric infections while the variations in $\mathrm{H}$. pylori detection and the associated risk factors investigated in the study were not significantly related.

Keywords: H. pylori, Peptic ulcer, PCR assay, Virulence genes, cagA, dupA, And vacA, Patients

\footnotetext{
* Correspondence: dejimicro@yahoo.com

${ }^{1}$ Department of Biochemistry and Microbiology, University of Fort Hare, Alice,

Eastern Cape 5700, South Africa

Full list of author information is available at the end of the article
}

(c) The Author(s). 2019 Open Access This article is distributed under the terms of the Creative Commons Attribution 4.0 International License (http://creativecommons.org/licenses/by/4.0/), which permits unrestricted use, distribution, and reproduction in any medium, provided you give appropriate credit to the original author(s) and the source, provide a link to the Creative Commons license, and indicate if changes were made. The Creative Commons Public Domain Dedication waiver (http://creativecommons.org/publicdomain/zero/1.0/) applies to the data made available in this article, unless otherwise stated. 


\section{Background}

The global prevalence of $H$. pylori approaches $50 \%$ (approximately 4.4 billion individuals infected), with prevalence rates between 20 and $40 \%$ in developed countries and up to $90 \%$ in Africa and other developing nations of the world [1]. The prevalence of infection differs among the population of people and within countries in relation to race, ethnicity, and geographical location [2]. In South Africa, the high prevalence of infection with the pathogen is common in children and adults [3]. A prevalence of $87 \%$ was reported in the Eastern Cape among asymptomatic individuals [4]. Furthermore, the prevalence of 13.5 to $84.2 \%$ was reported in pediatric subjects of Bloemfontein, 66\% in black children of KwaZulu/Natal, and 50.6\% in Thohoyandou [5]. Variations in the prevalence rates have been attributed to factors such as low socio-economic conditions, poor hygiene, and overcrowding in residences [4]. Though mode of transmission is still unclear, many authors have suggested fecal-oral routes via contaminated water, food and unwashed hands [6, 7]. The smoking of cigarette, alcohol consumption, diet, occupational exposure, individual genetic trait have been demonstrated as risk factors associated with infection of H. pylori [8]. However, oftentimes the results are inconsistent, with some studies indicating no difference in prevalence compared to a control group [9], while others display a lower or a higher prevalence $[10,11]$.

Several diagnostic methods (both invasive and non-invasive) have been described to detect $H$. pylori infection for epidemiological studies [12]. In the current study, we used a culture method and polymerase chain reaction (PCR) assay to isolate and detect or confirm $H$. pylori respectively. The two diagnostic methods have been reported to be specific and sensitive while on several occasions regarded as gold standards [13]. However, due to the long duration of incubation and false negative results, the culture method is usually avoided. Some studies have embraced a seroprevalence approach, which detects the antibodies but is unable to differentiate passive and active infection.

On the basis of disease progression, development of ailment depends on bacteria strain, host body, and environmental factors. Induction and progression of $H$. pylori-associated diseases are determined by a number of virulence factors [14]. Among them, the cytotoxin-associated gene A ( cagA), vacuolating cytotoxin gene A (vacA) and duodenal ulcer promoting gene $\mathrm{A}(\operatorname{dup} \mathrm{A})$ virulence markers have been widely studied [15]. The cagA has been described as the first bacterial oncoprotein and probably the virulence factor with the most important potential of $H$. pylori [16] while vacA toxin plays a significant role in immune modulation as well as in the induction of gastric cancer [17]. Selection of virulence markers is vital when using them to determine the risk of diseases. For instance, the $\operatorname{cagA}, \operatorname{dup} \mathrm{A}$ and vacA genes have been considered important virulence factors in relation to gastroduodenal diseases both in children and adults in Brazil [18]. Furthermore, cagA and vacA genotypes have been implicated with gastric diseases in Pakistan [24]. Similarly, development of a duodenal ulcer in a South East Indian Population was seen as a result of the presence of dupA in $H$. pylori [20]. Elsewhere in Iran, infection with $H$. pylori dupA negative strains was associated with high risk of development of stomach ulcer and cancer [21].

In Soweto, South Africa, existing data on the subject are few [22]. Thus, there is a need for a recent study to provide information on $H$. pylori virulence factors and their roles in the development of gastroduodenal diseases. Therefore, this study was aimed at determining the prevalence of $H$. pylori, detect the presence of $c a g \mathrm{~A}$, $v a c \mathrm{~A}$ and $d u p \mathrm{~A}$ virulence genes in patients at Chris Hani Baragwanath Academic Hospital and to analyze the relationship between these virulence genes and gastroduodenal disease development. The study also investigated the risk factors associated with gastroduodenal diseases among participants.

\section{Methods}

\section{Patient recruitment}

Patients were recruited in the gastrointestinal tract (GIT) unit of the Chris Hani Baragwanath Academic Hospital (CHBAH) between August 2017 and February 2018. Only those who gave consent were enrolled. The study included those with stomach affliction and referred for a non-sedated upper gastrointestinal endoscopy excluding patients recently on antibiotics and other eradication therapies in the last 3 months. Research questionnaires [Additional file 1] were administered to volunteered participants. The hospital $(\mathrm{CHBAH})$ is a public health institution located in the Soweto area of Johannesburg (GPS coordinates $26.2612^{\circ} \mathrm{S}, 27.9426^{\circ} \mathrm{E}$ ). It is known as the third largest hospital in the world with approximately 3200 beds. The hospital has a well functional GIT clinic which enrolls the highest number of patients in the country (over 2000 procedures annually). It is run by the Gauteng Provincial Health Authority and also a Teaching Hospital affiliated to the Medical School of The University of the Witwatersrand.

\section{Collection of biopsies}

A consultant gastroenterologist performed the endoscopy. Patients with different gastroduodenal related pathologies were sampled. Gastric biopsies were obtained from antrum and corpus of the stomach using jumbo forceps (Boston Scientific South Africa (Pty) Ltd.) 
and transferred into vials containing portagerm pylori [23] and cultured within $4 \mathrm{~h}$ after collection.

\section{Isolation of $\boldsymbol{H}$. pylori}

Biopsy specimens were aseptically rolled over the surface of Columbia blood agar base plates under a biological safety cabinet (Thermo Scientific). The agar (Oxoid CM0331) was supplemented with $7 \%$ horse serum (Oxoid SR0048), 1\% vitamin mix (Isovitalex), and an $H$. pylori selective supplement (Dent, SR0147E Oxoid) comprising of amphotericin B (2.5 mg), trimethoprim (2.5 mg), vancomycin $(5.0 \mathrm{mg})$, and cefsulodin $(2.5 \mathrm{mg})$. The plates were incubated at $37{ }^{\circ} \mathrm{C}$ in an atmosphere of $85 \% \mathrm{~N}_{2}, 10 \% \mathrm{CO}_{2}$ and $5 \% \mathrm{O}_{2}$ for 4-10 days. Presumptive H. pylori colonies were identified as small, round, translucent, Gram-negative and positive for catalase, oxidase and urease tests. The confirmed isolates were Frozen in brain heart infusion broth (BHI) containing 20\% glycerol and stored at $-80^{\circ} \mathrm{C}$ for future use.

\section{DNA extraction}

Total genomic DNA was extracted from biopsy tissues and cultured isolates using a commercial kit (QIAamp DNA Mini Kit; Qiagen, Hilden, Germany), according to the manufacturer's instructions. Briefly, biopsies were lysed in $180 \mu \mathrm{l}$ of ATL buffer and $20 \mu \mathrm{l}$ of proteinase K at $56^{\circ} \mathrm{C}$ for overnight incubation. Two hundred microliter of AL buffer was added to the lysate and samples were incubated for $10 \mathrm{~min}$ at $70^{\circ} \mathrm{C}$. After the addition of $200 \mu \mathrm{l}$ absolute ethanol, lysates were purified over a QIAamp column as specified by the manufacturer. The column was washed stepwisely with $500 \mu \mathrm{l}$ buffer AW1 and buffer AW2, after which an ultra-pure DNA product was eluted for PCR assay.

\section{Molecular confirmation of $H$. pylori}

PCR was performed on extracted DNA from biopsies using primers specific for $H$. pylori $16 \mathrm{~S}$ rRNA under the following conditions: Initial denaturation of $95^{\circ} \mathrm{C}$ for 5 mins and 35 cycles of $95^{\circ} \mathrm{C}$ for $30 \mathrm{~s}, 54{ }^{\circ} \mathrm{C}$ for $30 \mathrm{~s}$ and $72{ }^{\circ} \mathrm{C}$ for $30 \mathrm{~s}$ and a final extension time of $72^{\circ} \mathrm{C}$ for 10 min. The PCR amplification was performed using a thermocycler system (Bio-Rad Thermal cycler, Singapore). Each $25 \mu \mathrm{l}$ PCR reaction mixture contained $12.5 \mu \mathrm{l}$ PCR master mix (Promega, GoTag ${ }^{\circledR}$ Green Master Mix, USA), $0.5 \mu \mathrm{l}$ each of primer (Metabion, Planegg, Germany), $5 \mu \mathrm{l}$ of template DNA and $6.5 \mu \mathrm{l}$ of PCR grade water. For each PCR experiment, appropriate positive and negative controls were included. The $H$. pylori strain $J 99$ and nuclease-free water were used as positive and negative controls respectively. To detect the amplified product, $5 \mu \mathrm{l}$ of amplicons was visualized by electrophoresis through a $1.5 \%$ agarose gel (Merck, SA) at $100 \mathrm{~V}$ for 40 min in 1X TAE buffer and stained with ethidium bromide $(500 \mathrm{ng} / \mathrm{ml})$ (Sigma-Aldrich, USA) using the gel documentation system (Alliance 4.7, France). Identification of the bands was established by comparison of the band sizes with molecular weight markers of 100-bp (Thermo Scientific, (EU) Lithuania). Samples were considered positive when the visible band was the same size as that of the positive control DNA. The primer for $110 \mathrm{bp}$ product of the $16 \mathrm{SrRNA}$ sequence represented by the forward primer sequence: 5'-CTGGAGAGA CTAAGCCCTCC-3' and the reverse one: 5'-ATTA CTGACGCTGATTGTGC-3' [24].

\section{Detection of virulence genes}

Virulence genes $c a g \mathrm{~A}, \operatorname{dup} \mathrm{A}$ and $v a c \mathrm{~A}$ (subtypes: s1, s2, $\mathrm{m} 1$, and $\mathrm{m} 2$ ) were detected using PCR specific primers (Table 1) with the same amplification conditions and assay protocol as earlier described.

\section{Statistical analysis}

Data were analyzed by a two by two table statistics and chi-square test to determine the association between H. pylori positivity and epidemiological risk factors, as well as virulence factors and gastroduodenal disease diagnosis using the SPSS statistical software package version 18.0 (SPSS, Inc., Chicago, IL) and Open Source Epidemiology Statistics for Public Health

Table 1 Primer sequences for PCR detection of virulence genes

\begin{tabular}{|c|c|c|c|c|}
\hline Target gene & Primer pair $\left(5^{\prime}-3^{\prime}\right)$ & Amplicon length (bp) & Control strains & References \\
\hline $\operatorname{cagA}$ & $\begin{array}{l}\text { F: ACCGCTCGAGAACCCTAGTCGGTAATGGG } \\
\text { R: CAGGTACCGCGGCCGCTTAAGATTITTGGAAACCAC }\end{array}$ & 981 & 199 & [25] \\
\hline $\operatorname{vacAs} 1 / \mathrm{S} 2$ & $\begin{array}{l}\text { F: ATGGAAATACAACAAACACAC } \\
\text { R: CTGCTTGAATGCGCCAAAC }\end{array}$ & $259 / 286$ & J99/T×30a & \\
\hline vacAm1 & $\begin{array}{l}\text { F: GGTCAAAATGCGGTCATGG } \\
\text { R: CCATTGGTACCTGTAGAAAC }\end{array}$ & 290 & J99 & \\
\hline vacAm2 & $\begin{array}{l}\text { F: CATAACTAGCGCCTTGCAC } \\
\text { R: GGAGCCCCAGGAAACATTG }\end{array}$ & 352 & B8 & \\
\hline dupA & $\begin{array}{l}\text { F: GACGATTGAGCGATGGGAATAT } \\
\text { R: CTGAGAAGCCTTATTATCTTGTTGG }\end{array}$ & 971 & P12/J99 & [26] \\
\hline
\end{tabular}


Version 3.01. $P$ values $<0.05$ were considered statistically significant.

\section{Results}

\section{Culture and PCR analysis}

Of the 444 recruited patients, $H$. pylori was obtained in 115 (25.9\%) from culture analysis in either antrum or corpus or both biopsies. Two hundred and seventeen patients $(48.9 \%)$ were positive by the PCR technique (from either antrum or corpus or both biopsies). Ninety-eight $(85.2 \%)$ of the patients positive for culture were detected in PCR, giving an overall prevalence of $52.7 \%$ (i.e. 234/444) (Fig. 1). Of the 115 isolates, 8 (7\%) were obtained from only antrum biopsies, 41 (35.6\%) from corpus tissues and 66 (57.4\%) from both specimens (Fig. 2). Overall, antrum had $16.7 \%(74 / 444)$ culture prevalence while corpus had $24.1 \%$ (107/444). Also, from the $217 \mathrm{H}$. pylori positive by the PCR assay, $132(60.8 \%)$ were positive for both antrum and corpus, 23 (10.6\%) for antrum biopsy only and 62 (28.6\%) for corpus only (Fig. 3). Therefore, PCR percentage prevalence for antrum was $34.9 \%(155 / 444)$ and corpus was $43.7 \%$ (194/ 444). Some of the agarose gels showing PCR products are presented in Fig. 4a-d.

\section{Participant gender and $H$. pylori status}

Of the 444 participants, 284 (64\%) were females and 160 (36\%) males. The age range was between 15 and 100 years, mean age was $52.7 \pm 16.3$ years, and 25\% (109/ 444 ) of subjects were below 40 years. Of the 284 females, $150(52.8 \%)$ were $H$. pylori positive while in males, 84 (52.5\%) of 160 were positive.

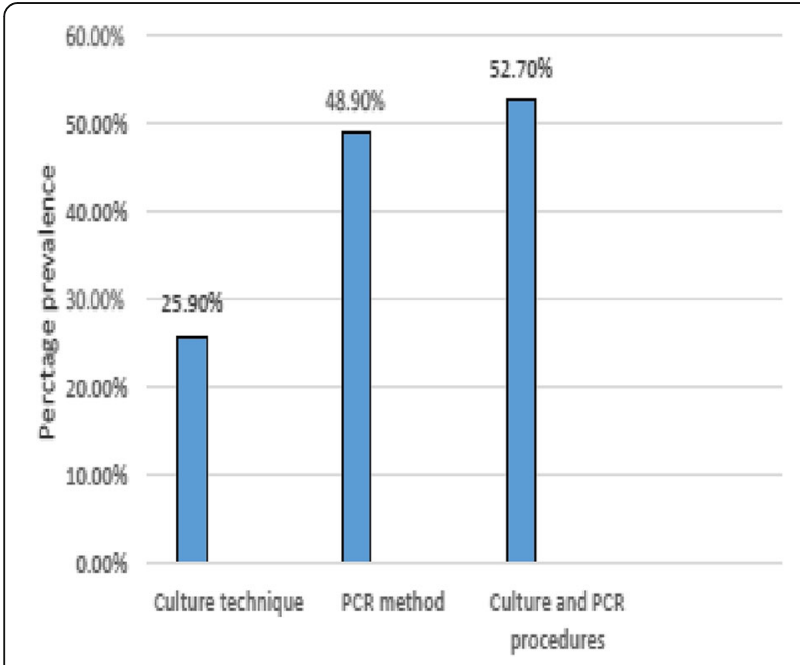

Fig. 1 H. pylori prevalence by culture and PCR methods

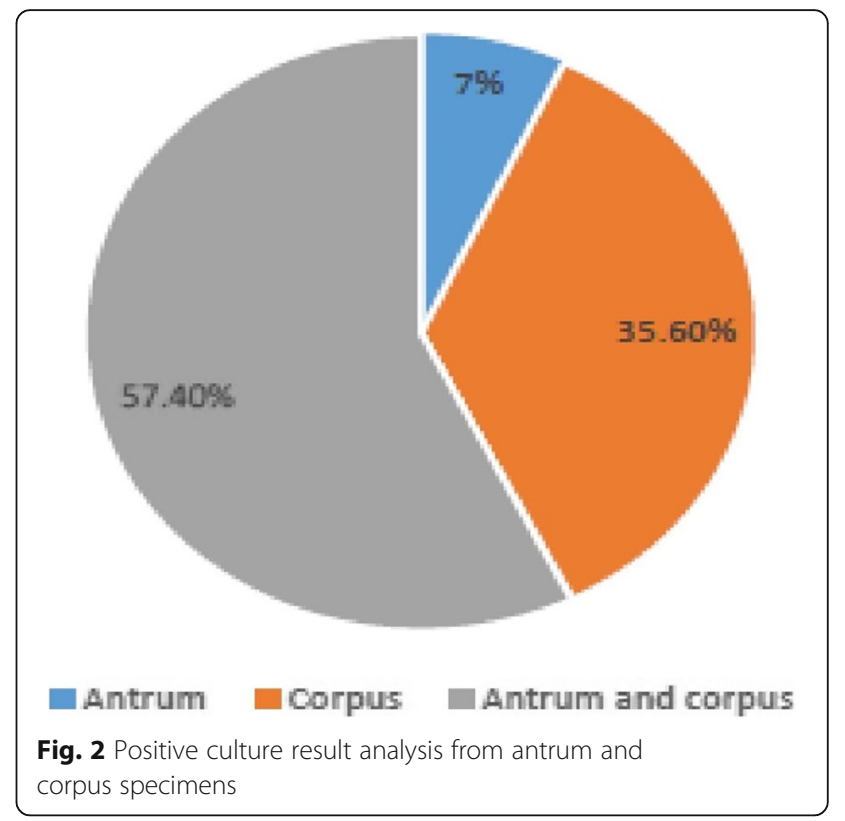

\section{Influence of epidemiological and socioeconomic risk factors}

Table 2 highlights epidemiological risk factors and socioeconomic conditions in $H$. pylori positivity. Patients with a family history of peptic ulcer and gastric cancer were $74(16.7 \%)$ and 39 (16.7\%) were positive for H. pylori. Two hundred and fifty-six $(57.7 \%)$ patients were living with more than three people and $H$. pylori was isolated in $141(60.3 \%)$ of this number. Thirteen $(2.9 \%)$ patients were drinking from untreated water sources and 6 (2.6\%) were H. pylori positive. Patients who smoke

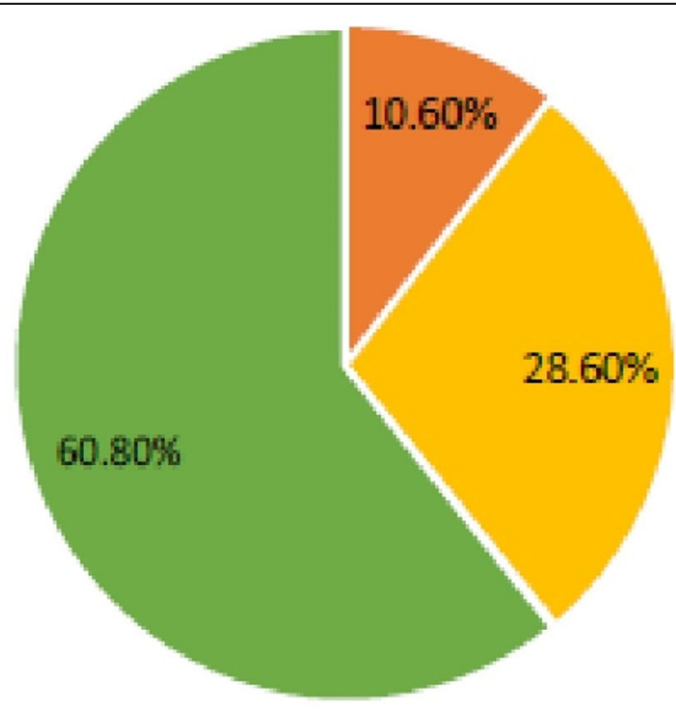

Antrum Corpus antrum and Corpus

Fig. 3 Positive PCR result analysis from antrum and corpus specimens 

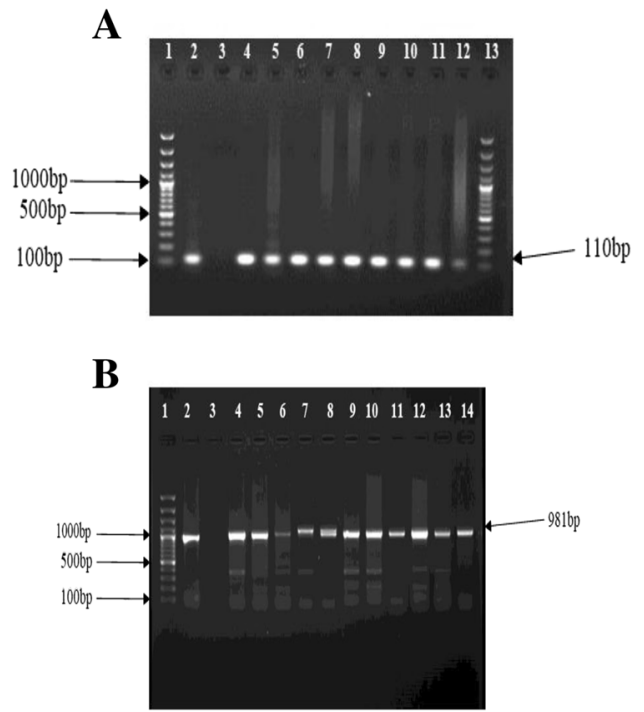

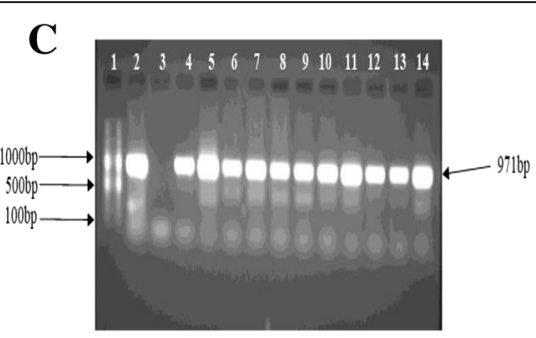

D

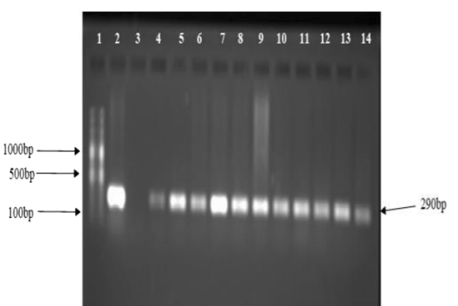

Fig. 4 a Agarose (1.5\%) gel electrophoresis of PCR products of the amplified 110 bp 165 rRNA gene. Lane 1 and 13: molecular weight markers (100 bp); lane 2: positive control (J99); lane 3: negative control (nuclease-free water); lanes 4-12: positive isolates. b Agarose (1.5\%) gel electrophoresis of PCR products for cagA (981 bp) detection. Lane 1: 100 bp gene ruler, Lanes 2: cagA positive control, lane 3: negative control, lanes 4-14: cagA positive isolates. c Agarose (1.5\%) gel electrophoresis of PCR products for dupA (971 bp) detection. Lane 1: 100 bp gene ruler, Lanes 2: dupA positive control, lane 3: negative control, lanes 4-14: dupA positive isolates. d Agarose (1.5\%) gel electrophoresis of PCR products for vacA m1 (290bp) detection. Lane 1: 100 bp gene ruler, Lane 2: vacA m1. positive control, lane 3: negative control, lanes 4-14: vacA m1 positive isolates

Table 2 Epidemiological risk factors and socioeconomic conditions of $H$. pylori infection

\begin{tabular}{|c|c|c|c|c|c|c|}
\hline Variables and categories & $\begin{array}{l}\text { Total participants } \\
\text { (\%) } n=444\end{array}$ & $\begin{array}{l}\text { H. pylori positive } \\
\text { (\%) } n=234\end{array}$ & $\begin{array}{l}\text { H. pylori negative } \\
\text { (\%) } n=210\end{array}$ & $\begin{array}{l}\text { Odd ratio } \\
(95 \% \mathrm{Cl})\end{array}$ & X2 test & $P$-value \\
\hline \multicolumn{7}{|c|}{ Family history of ulcer and cancer } \\
\hline Yes & $74(16.7)$ & $39(16.7)$ & $35(16.7)$ & 1 & \multirow[t]{2}{*}{0} & \multirow[t]{2}{*}{$>0.99$} \\
\hline No & $370(83.3)$ & $195(83.3)$ & $175(83.3)$ & $(0.61-1.65)$ & & \\
\hline \multicolumn{7}{|c|}{ Living with more than 3 people } \\
\hline Yes & $256(57.7)$ & $141(60.3)$ & $115(54.8)$ & 1.25 & \multirow[t]{2}{*}{1.37} & \multirow[t]{2}{*}{0.24} \\
\hline No & $188(42.3)$ & $93(39.7)$ & $95(45.2)$ & $(0.86-1.83)$ & & \\
\hline \multicolumn{7}{|c|}{ Drinking from untreated water sources (e.g. stream, river) } \\
\hline Yes & $13(2.9)$ & $6(2.6)$ & $7(3.3)$ & 0.76 & \multirow[t]{2}{*}{0.23} & \multirow[t]{2}{*}{0.63} \\
\hline No & $431(97.1)$ & $228(97.4)$ & $203(96.7)$ & $(0.25-2.31)$ & & \\
\hline \multicolumn{7}{|c|}{ Smoking and drinking of alcohol } \\
\hline Yes & $158(35.6)$ & $90(38.5)$ & $68(32.4)$ & 1.30 & \multirow[t]{2}{*}{1.78} & \multirow[t]{2}{*}{0.18} \\
\hline No & $286(64.4)$ & $144(61.5)$ & $142(67.6)$ & $(0.88-1.93)$ & & \\
\hline \multicolumn{7}{|c|}{ Involved in H. pylori risk occupation } \\
\hline Yes & $24(5.4)$ & $14(6)$ & $10(4.8)$ & 1.27 & \multirow[t]{2}{*}{0.32} & \multirow[t]{2}{*}{0.57} \\
\hline No & $420(94.6)$ & $220(94)$ & $200(95.2)$ & $(0.55-2.93)$ & & \\
\hline \multicolumn{7}{|l|}{ No Formal education } \\
\hline Yes & $32(7.2)$ & $18(7.7)$ & $14(6.7)$ & 1.17 & \multirow[t]{2}{*}{0.17} & \multirow[t]{2}{*}{0.68} \\
\hline No & $412(92.8)$ & $216(92.3)$ & $196(93.3)$ & $(0.56-2.41)$ & & \\
\hline \multicolumn{7}{|c|}{ Travelled outside the country within last 5 years for more than 1 month } \\
\hline Yes & $52(11.7)$ & $25(10.7)$ & $27(12.9)$ & 0.81 & \multirow[t]{2}{*}{0.51} & \multirow[t]{2}{*}{0.48} \\
\hline No & $392(88.3)$ & $209(89.3)$ & $183(87.1)$ & $(0.45-1.45)$ & & \\
\hline
\end{tabular}


and drink alcohol either regularly or occasionally were $158(35.6 \%)$ and 90 (38.5\%) of them were positive for $H$. pylori. Twenty-four (5.4\%) patients were involved in $H$. pylori risk occupations (e.g. people working directly with $H$. pylori-infected individuals such as medical practitioners) and 14 (6\%) were tested positive for $H$. pylori. Patients without formal education were 32 (9.8\%) and 18 (7.7\%) were H. pylori positive. Fifty-two (11.7\%) patients had traveled outside the country within the last 5 years for more than 1 month and 25 (10.7\%) tested positive. However, highlighted possible risk factors and socioeconomic conditions were not statistically significant $(P>0.05)$ (Table 2$)$.

Virulence gene detection and endoscopic conditions in $\mathrm{H}$. pylori positive individuals

The endoscopy grading in 444 participants showed normal mucosa in 17 (3.8\%) individuals, pan gastritis in 338 (76.1\%), peptic ulcers in 55 (12.4\%), gastric erosion in $23(5.2 \%)$, gastric cancer in $3(0.7 \%)$ and haemorrhages and polyps in $8(1.8 \%)$. The highest number of $H$. pylori positives [180 (76.9\%)] was obtained in pan gastritis patients, followed by participants with peptic ulcer 31 (13.2\%). No H. pylori isolate was obtained in participants with gastric cancer. Virulence genes were determined for all confirmed $H$. pylori positive patients obtained from culture isolates and biopsy DNA out of which the cagA gene was detected in $62 \%(145 / 234)$, dup $\mathrm{A}$ in $53.4 \%(125 / 234)$, vacAs1 in $66.2 \%(155 / 234)$, vacAs2 in $20.1 \%$ (47/234), vacAm1 in 69.2\% (162/234) and vacAm2 in $21.4 \%(50 / 234)$ strains.

The cagA virulence gene was highest [111 (76.5\%)] in pan gastritis patients followed by individuals with peptic ulcer [17 (11.7\%)], while participants with haemorrhages and polyps had the lowest cagA detection [2 (1.4\%)]. In this study, virulent allelic combination $\mathrm{s} 1 / \mathrm{m} 1$ was predominant and found in 132 (56.4\%) of the $H$. pylori strains, the $\mathrm{s} 1 / \mathrm{m} 2$ was detected in $22(9.4 \%)$ and the other genotypes, $\mathrm{s} 2 / \mathrm{m} 1$ and $\mathrm{s} 2 / \mathrm{m} 2$ were recorded in 24 (10.3\%) and $27(11.5 \%)$ strains respectively. Virulence genes $\operatorname{cag} \mathrm{A}, \operatorname{dup} \mathrm{A}, v a c \mathrm{~A} s 1 / \mathrm{m} 1$ were detected in all disease conditions except gastric cancer where $H$. pylori was not found. Detection of vacA s1 was significantly high $26(16.8 \%)$ in patients with peptic ulcer disease $(P=0.036)$. Similarly, vacA $\mathrm{s} 1 / \mathrm{m} 2$ was considerably high in patients with gastric erosion $(P=0.0029)$ (Table 3). Overall, $90.6 \%(212 / 234)$ of $H$. pylori strains were positive for $v a c \mathrm{~A}$ genotypes (data not exclusive but form unions and intersections).

\section{Association between cagA, dupA and vacA genotypes in H. pylori strains}

Table 4 shows the association between $\operatorname{cagA}$, $\operatorname{dup} \mathrm{A}$ and $v a c \mathrm{~A}$ genotypes in $H$. pylori strains. The vacA s1 was found to be significantly high $(P=0.000)$ in the cagA and $d u p \mathrm{~A}$ positives patients. Similarly, vacA $\mathrm{m} 1$ positive individuals recorded a significantly high cagA 123 (75.9\%) and dupA 100 (61.7\%) genotypes. Furthermore, there was a high detection rate of cagA 82.6\% (109/132) and dupA $63.6 \%(84 / 132)$ in the vacA $\mathrm{s} 1 / \mathrm{m} 1$ positive patients. The rest of the vacA genotypes were not significantly high in $c a g \mathrm{~A}$ and $d u p \mathrm{~A}$ positive individuals.

\section{Discussion}

Various diagnostic methods of detecting $H$. pylori have been proposed. The choice usually depends on the availability of materials, sampling population, condition of patients, and competency or experience of the

Table 3 Detection and distribution of $H$. pylori and its virulence genes in patients with various gastroduodenal disease outcomes

\begin{tabular}{|c|c|c|c|c|c|c|c|}
\hline & \multicolumn{6}{|c|}{ Disease conditions } & \multirow[b]{2}{*}{ Total (\%) } \\
\hline & $\begin{array}{l}\text { Normal mucosal } \\
\text { (\%) }\end{array}$ & $\begin{array}{l}\text { Pan gastritis } \\
\text { (\%) }\end{array}$ & $\begin{array}{l}\text { Peptic ulcer } \\
(\%)\end{array}$ & $\begin{array}{l}\text { Gastric erosion } \\
(\%)\end{array}$ & $\begin{array}{l}\text { Hemorrhages and } \\
\text { polyps (\%) }\end{array}$ & $\begin{array}{l}\text { Gastric cancer } \\
(\%)\end{array}$ & \\
\hline & $n=17$ (3.8) & $n=338(76.1)$ & $n=55(12.4)$ & $n=23(5.2)$ & $n=8(1.8)$ & $n=3(0.7)$ & $n=444(100)$ \\
\hline H. pylori positive & $9(3.8)$ & $180(76.9)$ & $31(13.2)$ & $11(4.7)$ & $3(1.3)$ & $0(0)$ & $234(100)$ \\
\hline $\operatorname{cag} \mathrm{A}$ & $7(4.8)$ & $111(76.5)$ & $17(11.7)$ & $8(5.5)$ & $2(1.4)$ & $0(0)$ & $145(100)$ \\
\hline dupA & $5(4.0)$ & $94(75.2)$ & $15(12.0)$ & $9(7.2)$ & $2(1.6)$ & $0(0)$ & $125(100)$ \\
\hline $\operatorname{vac} A s 1$ & $8(5.2)$ & $111(71.6)$ & $26(16.8) *$ & $7(4.5)$ & $3(1.9)$ & $0(0)$ & $155(100)$ \\
\hline $\operatorname{vac} A s 2$ & $1(2.1)$ & $38(80.9)$ & $5(10.6)$ & $3(6.4)$ & $0(0)$ & $0(0)$ & $47(100)$ \\
\hline vacAm1 & $6(3.7)$ & $123(75.9)$ & $23(14.2)$ & $7(4.3)$ & $3(1.9)$ & $0(0)$ & $162(100)$ \\
\hline vacAm2 & $3(6.0)$ & $37(74.0)$ & $7(14.0)$ & $3(6.0)$ & $0(0)$ & $0(0)$ & $50(100)$ \\
\hline $\operatorname{vac} A s 1 / m 1$ & $6(4.5)$ & $97(73.5)$ & $20(15.2)$ & $6(4.5)$ & $3(2.3)$ & $0(0)$ & $132(100)$ \\
\hline $\operatorname{vacAs} 1 / \mathrm{m} 2$ & $2(9.1)$ & $13(59.0)$ & $2(9.1)$ & $5(22.7) *$ & $0(0)$ & $0(0)$ & $22(100)$ \\
\hline $\operatorname{vacAs} 2 / \mathrm{m} 1$ & $0(0)$ & $19(79.2)$ & $3(12.5)$ & $2(8.3)$ & $0(0)$ & $0(0)$ & $24(100)$ \\
\hline $\operatorname{vacAs} 2 / \mathrm{m} 2$ & $1(3.7)$ & $22(81.5)$ & $2(7.4)$ & $2(7.4)$ & $0(0)$ & $0(0)$ & $27(100)$ \\
\hline
\end{tabular}

*Significant $(P<0.05)$ 
Table 4 Simultaneous detection of vacA, cagA and dupA in H. pylori strains

\begin{tabular}{llll}
\hline S/N & $\begin{array}{l}\text { vacA genotypes } \\
(\%) n=212\end{array}$ & $\begin{array}{l}\text { cagA positive } \\
(\%) n=145\end{array}$ & $\begin{array}{l}\text { dupA positive } \\
(\%) n=125\end{array}$ \\
\hline 1 & $s 1(n=155)$ & $122(78.7)^{*}$ & $97(62.6)^{*}$ \\
2 & $s 2(n=47)$ & $19(40.4)$ & $21(44.7)$ \\
3 & $\mathrm{~m} 1(n=162)$ & $123(75.9)^{*}$ & $100(61.7)^{*}$ \\
4 & $\mathrm{~m} 2(n=50)$ & $22(44.0)$ & $25(50.0)$ \\
5 & $s 1 / \mathrm{m} 1(n=132)$ & $109(82.6)^{*}$ & $84(63.6) *$ \\
6 & $s 1 / \mathrm{m} 2(n=22)$ & $13(59.1)$ & $12(54.5)$ \\
7 & $s 2 / \mathrm{m} 1(n=24)$ & $12(50.0)$ & $13(54.2)$ \\
8 & $s 2 / \mathrm{m} 2(n=27)$ & $10(37.0)$ & $12(44.4)$ \\
\hline
\end{tabular}

*significance $(P<0.05)$

investigator. In this study, the two methods complement each other for diagnosis and analysis. The choice of culture technique was based on a high record of specificity and availability of isolates for antibiotic susceptibility test. Similarly, PCR assay was chosen due to its high sensitivity reported by many authors [13]. Comparing both results, we observed a higher prevalence rate (48.9\%) in the PCR method than culture (25.9\%), given a difference of $23 \%$. The reason for the wide margin in the outcome of the two methods could be as a result of non-viability of some strains of $H$. pylori in agar medium as reported by some authors [27]. In this study, $85.2 \%$ of the culture-positive individuals were detected by the PCR assay. This outcome is below the expected 100\% positivity. This outcome may be due to different biopsies used for the analysis and sampling error occurs when the pathogen is not evenly distributed within the mucosa.

The overall prevalence of $52.7 \%$ obtained in the current study is relatively low compared to some other previous studies in developing nations where higher prevalence figures were recorded $[2,28]$. However, the outcome is not uncommon in South Africa as a lower rate $50.6 \%$ previously reported elsewhere in the country [5]. Furthermore, lower prevalence rates in some developing nations have been recently reported in Nigeria [25] Thailand [29], Indonesia [10] and Iran [30].

The bacterium is known to possess a wide degree of genomic and allelic diversity [31]. This special feature enables the organism to play an active role in the multiple gastric disorders in infected patients globally. One of the factors responsible for the multiple clinical presentations in individuals is a function of the bacterial virulence factors. This study, therefore, focused on the important virulence genes inducing gastroduodenal diseases among patients. The $c a g \mathrm{~A}$ and $v a c \mathrm{~A}$ have been related to inducing gastric adenocarcinoma, mucosal associated lymph tissue (MALT)-lymphoma, and peptic ulcer disease (PUD) in patients [32] while dupA is associated with duodenal ulcer [33]. Studies have revealed that the frequency and/or severity of gastroduodenal disease related to $H$. pylori varies geographically $[34,35]$. This proposition is somewhat due to a difference in the distribution pattern of virulence markers in circulating strains of the organism. For instance, it has been reported that East-Asian-type cagA with repeated EPIYA segment sequence A-B-D has a higher binding affinity than the western-type cagA with sequence A-B-C resulting in higher risk of peptic ulcer and gastric cancer [36]. Furthermore, a low incidence of gastric cancer and peptic ulceration has been reported in a population of a high percentage of $v a c \mathrm{~A} \mathrm{~m} 2$, dup $\mathrm{A}$ negative and cagA negative H. pylori strains [37].

In this study, to establish a possible association between the presence of the major virulence factors and disease outcome among patients attending $\mathrm{CHBAH}$, Soweto, we analyzed the status of $\operatorname{cagA}, v a c \mathrm{~A}$ and $\operatorname{dup\mathrm {A}}$ genotypes of $234 \mathrm{H}$. pylori strains. The majority of strains were vacA $90.6 \%(212 / 234)$, followed by cagA 62\% (145/234) and dupA 53.4\% (125/234). Among the $v a c \mathrm{~A}$ genotype combinations, vacA s1/m1 was the highest at $56.4 \%(132 / 234)$.

CagA is one of the most studied virulence genes of $H$. pylori and this toxic protein has a molecular size of 120 to $145 \mathrm{kDa}$ and is found on the cag-PAI. The strains that carry the PAI are known to be more virulent than those lacking it [38]. The prevalence of $62 \%$ cagA positive strains obtained in our study is similar to researches conducted in Tunisia and Morocco where 61.6 and $61.2 \% \operatorname{cagA}$ were reported respectively $[39,40]$. However, the outcome is lower compared to a higher prevalence cagA previously reported elsewhere in South Africa. For example, in Eastern Cape, South Africa, 90\% cagA positive strains were reported [41], while in Gauteng, $87 \%$ cases of cagA positive were found among asymptomatic children age between 6 and 15 years in another study. Globally, in Taiwan, $83 \%$ cagA positive strains were found in isolates from patients with chronic gastritis and peptic ulcer [42]. Among Turkish patients with dyspepsia, $74 \%$ cagA was detected [43] and $85 \%$ cagA was reported among Alaskans (USA) [44]. Also, 93\% in Nigeria [45] and 96\% in Indian [19]. On the other hand, a lower prevalence of cagA has been documented elsewhere such as Cuba [46], Pakistan, Egypt, Israel and Jordan [19].

Vacuolating cytotoxin $(v a c \mathrm{~A})$ has been implicated to play a major role in gastroduodenal disease progression. The gene is a pore-forming toxin secreted through an auto transporter. The mechanism of its toxigenic effect occurs by binding to the receptor of the eukaryotic cell lipid sphingomyelin. The gene targets the mitochondria where it induces apoptosis and formation of large intracellular vacuoles. VacA polymorphisms are divided into 
signal, intermediate, middle and deletion regions. Of all the allelic combinations, the $v a c \mathrm{~A} \mathrm{~s} 1 / \mathrm{m} 1$ alleles are the most virulent, while the $\mathrm{s} 1 / \mathrm{m} 2, \mathrm{~s} 2 / \mathrm{m} 1$ and $\mathrm{s} 2 / \mathrm{m} 2$ genotypes demonstrate little to no pathogenicity. Our study showed $v a c \mathrm{~A}$ s1 to be predominant, which is similar to findings reported elsewhere such as Eastern Cape South Africa [41], Thailand [29] and Indian [20]. In the same vein, Findings in Alaska (USA) [44], Cuba [46] and Morocco [40] showed the dominance of vacAs1 subtypes and its link with disease status. On the other hand, a lower prevalence of s1 type allele has been reported in Jordan [47] as well as Iran [48].

Generally, our finding shows a high prevalence of vacA genotypes (90.6\%) predominantly of the subtypes $\mathrm{s} 1$ and $\mathrm{m} 1$ which makes patients likely to be more prone to $H$. pylori-associated diseases. The absence of vacA in 22 strains in the study could be a result of the genetic structure of the strains or exposure to adverse stomach conditions [49]. In the study, the subtype vacA $\mathrm{m} 1$ (69.2\%) were more than vacA m2 (21.4\%). The outcome is in line with findings of other authors who reported a higher prevalence of vacA $\mathrm{m} 1$ than $\mathrm{m} 2$ [50-52]. However, other studies have reported contrary results $[41,43]$. Numerical data of vacA polymorphs differ from strains due to genetic composition and geographical location of the organism. For example, $\mathrm{m} 1$ genotype appears more than $\mathrm{m} 2$ in African population while the two subtypes are almost equally distributed within Europe and Latin America [53].

This result compared to a study conducted in Nigeria is lower in terms of the presence of $\operatorname{cagA}$ and $v a c \mathrm{~A}$ virulence genes among $H$. pylori strains [25]. However, no correlation with pathology could be observed in the Nigerian study contrary to our findings which showed a significant relationship between vacAs1 and peptic ulcer as well as $v a c \mathrm{As} 1 / \mathrm{m} 2$ and gastric erosion. The reason probably could be the influence of host genetic make-up and environmental conditions [54]. In the same vein, our finding is parallel with a study conducted in Brazil which showed that $v a c \mathrm{~A} \mathrm{~s} 1 / \mathrm{m} 1$ genotype may be considered an important virulence factor in the development of gastric diseases [18].

Duodenal ulcer promoting gene (dupA) has been considered as a marker for the peptic ulcers by some authors [18] but in our study, the association could not be linked. In line with our study, some authors were unable to regard $d u p \mathrm{~A}$ as a predictor of duodenal ulceration in Belgium, South Africa, China and North America [55]. We recorded 53.4\% dupA positive isolates in our study, while the lower prevalence of dupA (18.8\%) was reported in Northern Iraq [26] and as well as $39 \%$ in Iran [56].

H. pylori infection leads to several gastroduodenal diseases including gastric cancer. In this study, few cases of gastric cancer (3/444) occurred, but none was accompanied with $H$. pylori infection. Due to limited data of patients with gastric cancer, though not uncommon in Africa, we cannot extrapolate gastric cancer and $H$. pylori negativity. Some studies have described factors such as viral infection, habit, immunological disorders and gene mutations as the aetiology of gastric cancer [57]. This study contains findings from gastroenterology reports of patients, while detailed pathological examination by histological grading of stomach biopsies was omitted. We, therefore, hope to include histological examination in the future study to enable comparison with gastroenterology diagnosis.

\section{Conclusions}

The current study showed a vital correlation between vacAs1 and the development of peptic ulcer disease as well as $v a c \mathrm{As} 1 / \mathrm{m} 2$ and gastric erosion. In South Africa and other developing nations, the occurrence of $H$. pylori virulence factors is common, but their involvement as disease markers is not really pronounced. Studies of $H$. pylori virulence factors in South Africa could be important for a clinical and epidemiological survey to better understand the disease pathology.

\section{Additional files}

Additional file 1: Patient questionnaire. Contains patients investigation form, gastroenterology result sheet and consent form. (PDF $420 \mathrm{~kb}$ )

Additional file 2: Ethics certificate. Contains ethics certificates from the CHBAH and University of Fort Hare. (PDF $154 \mathrm{~kb}$ )

\section{Abbreviations}

BHI: Brain heart infusion; Cag PAl: cag Pathogenicity Island; CagA: Cytotoxinassociated gene A; CHBAH: Chris Hani Baragwanath Academic Hospital; DFG: Deutsche Forschungsgemeinschaft; DNA: Deoxyribonucleic acid; DupA: Duodenal ulcer promoting gene A; GIT: Gastro intestinal tract; PCR: Polymerase chain reaction; VacA ( $m$ and $s$ ): VacA (middle and signal); VacA: Vacuolating cytotoxin gene A

\section{Acknowledgments}

Authors are grateful to nurses (Sis. Patricia, Fikile, and Helen) and portal (Mr. Andrew) in GIT department of CHBAH Soweto for their involvement and cooperation. Thanks to all patients who volunteered to participate in our study. We show appreciation to Friederike Aicher for administrative support as well as Hassan Hashim and Mamello Lorraine for technical assistance. We thankful to Dr. Wadula and Prof. Candy for laboratory facilities provided during sampling at $\mathrm{CHBAH}$.

\section{Funding}

This project was sponsored by the Deutsche Forschungsgemeinschaft (DFG) in the context of the German African Infectiology Initiative (HA2697/18-1) to Rainer Haas, Stella Smith, and Anna Clarke. The funding body wrote the research proposal, secured an ethics approval for the study, designed the questionnaire, coordinated the activities during sample collection, monitored and ensured that each participant signed a written consent form. They captured, visualized, and validated data and also analyzed and interpreted results. They ensured that the work programme and study objectives were achieved within the speculated period among the collaborating countries. They read and edited the draft manuscript. 


\section{Availability of data and materials}

The data that support the findings of this study are not publicly available due to restriction by the Ethics Committee of Chris Hani Baragwanath Academic Hospital, Johannesburg, South Africa in order to protect patient privacy. Data are available from Henry Njom and Ayodeji Idowu Department of Biochemistry and Microbiology University of Fort Hare Alice Campus, South Africa for researchers who meet the criteria for access to confidential data.

\section{Authors' contributions}

Conception and design of the study: RH, SS, AC. Endoscopy and collection of biopsies: RA, MM, RM, JB. Methodology and laboratory investigation: Al, AM, $\mathrm{HN}, \mathrm{UH}, \mathrm{PP}, \mathrm{TJ}$. Questionnaire design/administration/ data curation and analysis: Al, AM, HN, UH, PP, SS, TJ. Writing of original manuscript: Al. Editing and review of manuscript: Al, HN, RH, SS, PP. All authors read and approved the final manuscript.

\section{Ethics approval and consent to participate}

The research protocol was reviewed and approved by the Ethics Committee of the University of Fort Hare Eastern Cape South Africa (registration number Rec-270710-028-RA level 01) and by the management of Chris Hani Baragwanath Academic Hospital (CHBAH), Soweto South Africa (registration number M160228) [Additional file 2]. Written informed consent was obtained from all participants while for the patients below 18 years, consents were gotten from their parents or guardians after telling them the significance of the research. The study was conducted in accordance with the Helsinki declaration.

\section{Consent for publication}

Not applicable.

\section{Competing interests}

The authors declare that they have no competing interests.

\section{Publisher's Note}

Springer Nature remains neutral with regard to jurisdictional claims in published maps and institutional affiliations.

\section{Author details}

${ }^{1}$ Department of Biochemistry and Microbiology, University of Fort Hare, Alice, Eastern Cape 5700, South Africa. ${ }^{2}$ Chair of Medical Microbiology and Hospital Epidemiology, Max von Pettenkofer-Institute, Faculty of Medicine, LMU Munich, Munich, Germany. ${ }^{3}$ Division of Gastroenterology, Chris Hani Baragwanath Academic Hospital (CHBAH), Soweto, Johannesburg 2013, South Africa. ${ }^{4}$ Department of Microbiology, University of Lagos, Akoka, Yaba Lagos, Nigeria. ${ }^{5}$ Molecular Biology Department, Nigerian Institute of Medical Research, Yaba, Lagos, Nigeria.

Received: 1 October 2018 Accepted: 11 April 2019

Published online: 14 May 2019

\section{References}

1. Hooi JKY, Lai WY, Ng WK, Suen MMY, Underwood FE, Tanyingoh D, et al. Global prevalence of Helicobacter pylori infection: systematic review and meta-analysis. Gastroenterology. 2017;153(2):420-9. Available from http:// www.ncbi.nlm.nih.gov/pubmed/28456631

2. Tanih NF, Ndip RN. A South African perspective on Helicobacter pylori: prevalence, epidemiology and antimicrobial chemotherapy. African J Microbiol Res. 2013;7(21):2430-7. Available from https://pdfs. semanticscholar.org/b982/f504624a804b09cde7fea49468e27c44e4c7.pdf.

3. Kidd M, Louw JA, Marks IN. Helicobacter pylori in Africa: Observations on an "enigma within an enigma.". J Gastroenterol Hepatol. 1999;14(9):851-8.

4. Dube C, Tanih NF, Clarke AM, Mkwetshana N, Green E, Ndip RN. Helicobacter pylori infection and transmission in Africa: household hygiene and water sources are plausible factors exacerbating spread. African J Biotechnol. 2009; 8(22):6028-35. Available from http://citeseerx.ist.psu.edu/viewdoc/ download?doi=10.1.1.474.4239\&rep=rep1\&type=pdf.

5. Samie A, Obi CL, Barrett LJ, Powell SM, Guerrant RL. Prevalence of Campylobacter species, Helicobacter pylori and Arcobacter species in stool samples from the Venda region, Limpopo, South Africa: studies using molecular diagnostic methods. J Inf Secur. 2007;54(6):558-66.
6. Brown LM. Helicobacter pylori: epidemiology and routes of transmission. Epidemiol Rev. 2000;22(2):283-97.

7. Aziz RK, Khalifa MM, Sharaf RR. Contaminated water as a source of Helicobacter pylori infection: A review. J Adv Res. 2015;6:539-47.

8. Eusebi LH, Zagari RM, Bazzoli F. Epidemiology of Helicobacter pylori infection. Helicobacter. 2014:19(S1):1-5.

9. Kameswara S, Mynepalli C, Maureen O, Mumuni A. Prevalence of Helicobacter pylori and hygiene practices among public secondary school students in Ikeja local government area, Lagos, Nigeria. Health. 2014;6(4):250-8.

10. Syam AF, Miftahussurur M, Makmun D, Nusi IA, Zain LH, Zulkhairi, et al. Risk factors and prevalence of Helicobacter pylori in five largest islands of Indonesia: a preliminary study. PLoS One. 2015;10(11):1-14.

11. Tanih NF, Okeleye BI, Ndip LM, Clarke AM, Naidoo N, Mkwetshana N, et al. Helicobacter pylori prevalence in dyspeptic patients in the eastern Cape Province - race and disease status. South African Med J. 2010;100(11):734-7.

12. Aftab H, Miftahussurur M, Subsomwong P, Ahmed F, Azad AK. Original article Helicobacter pylori antibiotic susceptibility patterns in Bangladesh emerging levofloxacin resistance. J Infect Dev Ctries. 2016;10(3):245-53. https://doi.org/10.3855/jidc.7713.

13. Patel SK, Pratap CB, Jain AK, Gulati AK, Nath G. Diagnosis of Helicobacter pylori: what should be the gold standard? World J Gastroenterol. 2014; 20(36):12847-59.

14. Yamaoka Y. Mechanisms of disease: Helicobacter pylori virulence factors. Nat Rev Gastroenterol Hepatol. 2011;7(11):629-41 Available from: https://doi.org/ 10.1038/nrgastro.2010.154

15. Roesler BM. Clinical medicine insights : gastroenterology virulence factors of Helicobacter pylori : a review. Clin Med Insights Gastroenterol. 2014;7:9-17.

16. Hatakeyama M. Review Helicobacter pylori CagA and Gastric Cancer. Cell Host Microbe. 2014;15(3):306-16 Available from: https://doi.org/10.1016/j. chom.2014.02.008.

17. Utsch C, Haas R. VacA's induction of VacA-containing vacuoles (VCVs) and their immunomodulatory activities on human T cells. Toxins (Basel). 2016; 8(6):190.

18. Pereira WN, Ferraz MA, Zabaglia LM, de Labio RW, Orcini WA, Bianchi Ximenez JP, et al. Association among H. pylori virulence markers dupA, cagA and vacA in Brazilian patients. J Venom Anim Toxins Incl Trop Dis. 2014; 20(1):1. Available from: https://www.ncbi.nlm.nih.gov/pmc/articles/ PMC3922733/pdf/1678-9199-20-1.pdf.

19. Ahmad T, Sohail K, Rizwan M, Mukhtar M, Bilal R, Khanum A. Prevalence of Helicobacter pylori pathogenicity-associated cagA and vacA genotypes among Pakistani dyspeptic patients: research article. FEMS Immunol Med Microbiol. 2009;55(1):34-8.

20. Alam J, Maiti S, Ghosh P, De R, Chowdhury A, Das S, et al. Significant association of the dupA gene of Helicobacter pylori with duodenal ulcer development in a south-east Indian population. J Med Microbiol. 2012;61: 1295-302.

21. Abadi ATB, Taghvaei T, Wolfram L, Kusters JG. Infection with Helicobacter pylori strains lacking dupA is associated with an increased risk of gastric ulcer and gastric cancer development. J Med Microbiol. 2012;61(1):23-30.

22. Duncan SS, Bertoli MT, Kersulyte D, Valk PL, Tamma S, Segal I, et al. Genome sequences of three hpAfrica2 strains of Helicobacter pylori. Genome Announcement. 2013;1(5):9-10.

23. Grove DI, McLeay RAB, Byron KE, Koutsouridis G. Isolation of Helicobacter pylori after transport from a regional laboratory of gastric biopsy specimens in saline, portagerm pylori or cultured on chocolate agar. Pathology. 2001; 33(3):362-4

24. Ghorbani F, Gheisari E, Dehkordi FS. Genotyping of vacA alleles of Helicobacter pylori strains. Tropical J of Pharm Res. 2016;15(August):1631-6.

25. Harrison U, Fowora MA, Seriki AT, Loell E, Mueller S, Ugo-ljeh M, et al. Helicobacter pylori strains from a Nigerian cohort show divergent antibiotic resistance rates and a uniform pathogenicity profile. PLoS One. 2017;12(5):1-16.

26. Salih AM, Goreal A, Hussein NR, Abdullah SM, Hawrami K, Assafi M. The distribution of cagA and dupA genes in Helicobacter pylori strains in Kurdistan region, northern Iraq. Ann Saudi Med. 2013;33(3):290-3.

27. Willén R, Carlén B, Wang X, Papadogiannakis N, Odselius R, Wadström T. Morphologic conversion of Helicobacter pylori from spiral to coccoid form. Scanning (SEM) and transmission electron microscopy (TEM) suggest viability. Ups J Med Sci. 2000;105(1):31-40.

28. Kidd M, Peek RM, Lastovica AJ, Israel DA, Kummer AF, Louw JA, et al. Analysis of iceA genotypes in South African Helicobacter pylori strains and relationship to clinically significant disease. GUT. 2001;49:629-35. 
29. Subsomwong P, Miftahussurur M, Uchida T, Vilaichone R, Ratanachuek T, Mahachai $V$, et al. Prevalence, risk factors, and virulence genes of Helicobacter pylori among dyspeptic patients in two different gastric cancer risk regions of Thailand. PLoS One. 2017;12(10):e0187113. Available from https://journals.plos.org/plosone/article/file?id=10.1371/journal.pone. 0187113\&type $=$ printable.

30. Dadashzadeh K, Peppelenbosch MP, Adamu Al. Helicobacter pylori pathogenicity factors related to gastric cancer. Can J Gastroenterol Hepatol. 2017:2017:1-6

31. Suerbaum S, Josenhans C. Helicobacter pylori evolution and phenotypic diversification in a changing host. Nat Rev Microbiol. 2007;5(6):441-52

32. Chang WL, Yeh YC, Sheu BS. The impacts of $H$. pylori virulence factors on the development of gastroduodenal diseases. J Biomed Sci. 2018; 25(1):1-9.

33. Shiota S, Matsunari O, Watada M, Hanada K, Yamaoka Y. Systematic review and meta-analysis: the relationship between the Helicobacter pylori dupA gene and clinical outcomes. Gut Pathog. 2010;2(1):1-6.

34. Souod N, Kargar M, Doosti A, Ranjbar R, Sarshar M. Genetic analysis of cagA and vacA genes in Helicobacter Pylori isolates and their relationship with gastroduodenal diseases in the west of Iran. Iran Red Crescent Med J [Internet]. 2013;15(5):371-5. Available from https://www.ncbi.nlm.nih.gov/ pmc/articles/PMC3838643/pdf/ircmj-15-371.pdf.

35. Vale FF, Nunes A, Oleastro M, Gomes JP, Sampaio DA, Rocha R, et al. Genomic structure and insertion sites of Helicobacter pylori prophages from various geographical origins. Sci Rep. 2017;7(July 2016):1-12.

36. Miftahussurur M, Syam AF, Makmun D, Nusi IA, Zein LH, Zulkhairi, et al. Helicobacter pylori virulence genes in the five largest islands of Indonesia. Gut Pathog. 2015;7(1):1-10

37. Amieva M, Peek RM. Pathobiology of Helicobacter pylori-Induced Gastric Cancer. Gastroenterology. 2016;150(1):64-78.

38. Fischer W. Assembly and molecular mode of action of the Helicobacter pylori cag type IV secretion apparatus. FEBS J. 2011;278(8):1203-12.

39. Ben Mansour K, Fendri C, Zribi M, Masmoudi A, Labbene M, Fillali A, et al. Prevalence of Helicobacter pylori vacA, cagA, iceA and oipA genotypes in Tunisian patients. Ann Clin Microbiol Antimicrob. 2010;9(m):10.

40. El Khadir M, Alaoui Boukhris S, Benajah DA, El Rhazi K, Adil Ibrahimi S, El Abkari M, et al. VacA and CagA status as a biomarker of two opposite end outcomes of Helicobacter pylori infection (gastric cancer and duodenal ulcer) in a Moroccan population. PLoS One. 2017;12(1):1-14.

41. Tanih NF, McMillan M, Naidoo N, Ndip LM, Weaver LT, Ndip RN. Prevalence of Helicobacter pylori vacA, cagA and iceA genotypes in south African patients with upper gastrointestinal diseases. Acta Trop. 2010;116(1):68-73 Available from: https://doi.org/10.1016/j.actatropica.2010.05.011.

42. Lin H-J, Perng C-L, Lo W-C, Wu C-W, Tseng G-Y, Li A-F-Y, et al. Helicobacter pylori cagA, iceA and vacA genotypes in patients with gastric cancer in Taiwan. World J Gastroenterol WJG. 2004;10(17):2493-7. Available from https://www.researchgate.net/publication/8410071_Helicobacter_pylori_ cagA_iceA_and_vacA_genotypes_in_patients_with_gastric_cancer_in_ Taiwan.

43. Ozbey G, Dogan Y, Demiroren K. Prevalence of Helicobacter pylori virulence genotypes among children in Eastern Turkey. World J Gastroenterol. 2013; 19(39):6585-9.

44. Miernyk K, Morris J, Bruden D, McMahon B, Hurlburt D, Sacco F, et al. Characterization of Helicobacter pylori cagA and vacA genotypes among Alaskans and their correlation with clinical disease. J Clin Microbiol. 2011; 49(9):3114-21.

45. Smith SI, Kirsch C, Oyedeji KS, Arigbabu AO, Coker AO, Bayerdoffer E. Prevalence of Helicobacter pylori VacA, Cag A and ice a genotypes in Nigerian patients with duodenal ulcer disease. J Med Microbiol. 2002; 51(2002):851-4.

46. Feliciano $O$, Gutierrez $O$, Valdés L, Fragoso $T$, Calderin AM, Valdes $A E$, et al. cagA, and iceA genotypes in Cuban patients with upper gastrointestinal diseases. Biomed Res Int. 2015; 1-6. Article ID 753710. https://www.ncbi.nlm. nih.gov/pmc/articles/PMC4402555/pdf/BMRI2015-753710.pdf.

47. Nimri LF, Matalka I, Hani KB, Ibrahim M. Helicobacter pylori genotypes identified in gastric biopsy specimens from Jordanian patients. BMC Gastroenterol. 2006;6:1-6.

48. Pajavand H, Alvandi A, Mohajeri P, Bakhtyari S, Bashiri H, Kalali B, et al. High frequency of vacA s1m2 genotypes among Helicobacter pylori isolates from patients with gastroduodenal disorders in Kermanshah, Iran. Jundishapur J Microbiol. 2015;8(11):1-7
49. Da Costa DM, Dos Santos PE, Rabenhorst SHB. What exists beyond cagA and vacA? Helicobacter pylori genes in gastric diseases. World J Gastroenterol. 2015;21(37):10563-72.

50. Matsunari O, Shiota S, Suzuki R, Watada M, Kinjo N, Murakami K, et al. Association between Helicobacter pylori virulence factors and gastroduodenal diseases in Okinawa, Japan. J Clin Microbiol. 2012;50(3):876-83.

51. Trang $\Pi T H$, Shiota S, Matsuda M, Binh TT, Suzuki R, Vilaichone R, et al. The Prevalence of Helicobacter pylori virulence factors in Bhutan, Vietnam, and Myanmar is related to gastric cancer incidence. Biomed Res Int. 2015;2015: 1-8 Available from: http://www.hindawi.com/journals/bmri/2015/830813/.

52. Vannarath S, Vilaichone R, Rasachak B, Mairiang P, Yamaoka Y, Shiota S, et al Virulence genes of Helicobacter pylori in gastritis, peptic ulcer and gastric cancer in Laos. Asian Pac J Cancer Prev. 2014;15(20):9027-31 Available from: https://www.ncbi.nlm.nih.gov/pubmed/25374247.

53. Ghose C, Perez-Perez GI, Van Doorn LJ, Domínguez-Bello MG, Blaser MJ. High frequency of gastric colonization with multiple Helicobacter pylori strains in Venezuelan subjects. J Clin Microbiol. 2005;43(6):2635-41.

54. Uchida T, Nguyen LT, Takayama A, Okimoto T, Kodama M, Murakami K, et al. Analysis of virulence factors of Helicobacter pylori isolated from a Vietnamese population. BMC Microbiol. 2009;9(1):175 Available from: https://bmcmicrobiol.biomedcentral.com/articles/10.1186/1471-2180-9-175.

55. Argent $\mathrm{RH}$, Burette $\mathrm{A}$, Deyi $\mathrm{VYM}$, Atherton JC. The presence of dupA in Helicobacter pylori is not significantly associated with duodenal ulceration in Belgium, South Africa, China, or North America. Clin Infect Dis. 2007;45(9): 1204-6 Available from: http://www.ncbi.nlm.nih.gov/pubmed/17918084.

56. Dadashzadeh K. Relevance of Helicobacter pylori dupA and OipA genotypes and development of the gastric disease. Biomed Res. 2017;28(19):8179-83.

57. Yamamoto Y, Fujisaki J, Omae M, Hirasawa T, Igarashi M. Helicobacter pylorinegative gastric cancer : characteristics and endoscopic findings. Diagnostic Endoscopy. 2016:58(9):1492-503.

Ready to submit your research? Choose BMC and benefit from:

- fast, convenient online submission

- thorough peer review by experienced researchers in your field

- rapid publication on acceptance

- support for research data, including large and complex data types

- gold Open Access which fosters wider collaboration and increased citations

- maximum visibility for your research: over $100 \mathrm{M}$ website views per year

At $\mathrm{BMC}$, research is always in progress.

Learn more biomedcentral.com/submissions 